\title{
Invasive terrestrial plant species in the Romanian protected areas. A review of the geographical aspects
}

\author{
Ines Grigorescu $^{1}$, Gheorghe Kucsicsa ${ }^{1 *}$, Monica Dumitrașcu ${ }^{1}$, Mihai Doroftei ${ }^{2}$ \\ 'Institute of Geography, Romanian Academy, 12 D. Racoviţă Street, sect. 2, 023993, Bucharest, Romania \\ ${ }^{2}$ Danube Delta National Institute, 165 Babadag Street, 820112, Tulcea, Romania
}

\begin{abstract}
Grigorescu, I., Kucsicsa, G., Dumitraşcu, M., Doroftei, M., 2020. Invasive terrestrial plant species in the Romanian protected areas. A review of the geographical aspects. Folia Oecologica, 47 (2): 168-177.

Geographical factors play an essential role in the occurrence and spread of invasive species worldwide, and their particular analysis at regional and local scales becomes important in understanding species development patterns. The present paper discusses the relationships between some key geographical factors and the Invasive Terrestrial Plant Species (ITPS) distribution, and their environmental implications in a few protected areas in Romania. The authors focused their attention on three of the foremost invaders (i.e. Amorpha fruticosa, Ailanthus altissima and Fallopia japonica) making use of the information provided by the scientific literature and some illustrative examples developed in the framework of the FP7 enviroGRIDS project. The study is aimed to increase the knowledge of the ITPS and, specifically, to contribute to the geographical understanding of the role played by the driving factors in their distribution and spread in various habitats and ecosystems. The results will further support the control efforts in protected areas where, often, valuable native species are at risk of being replaced by non-native species.
\end{abstract}

\section{Keywords}

geographical factors, Invasive Terrestrial Plant Species (ITPS), national/natural parks, potential distribution

\section{Introduction}

Over the last decades, the world has witnessed unprecedented transformations driven by a variety of socio-economic and spatial process (e.g. population growth, urban expansion, land use/cover changes) leading to habitats fragmentation, a decline of ecosystem services, biodiversity loss etc. One major consequence of these complex global environmental changes is the progressive spread of invasive species beyond natural geographic barriers (DumitrașCU and Grigorescu, 2016).

The likelihood of species to be introduced, established, and then spread (the introduction-naturalization-invasion continuum) is affected by a variety of factors which also includes geographical, ecological, socio-economic drivers (RICHARDSON and PyšEK, 2012; RoJAS-SANDOval et al.,
2017). According to the pan-European project DAISIE (www.europe-aliens.org), which provided the most comprehensive image of the biological invasions in Europe (LAMBDON et al., 2008), a total of 12,000 non-native species were recorded, which is most probably an underestimation of the real figures (GALLARDO, 2014). The invasive species have continuously spread and become successfully established throughout Europe, causing major environmental and socio-economic damages (PYSEK and Hulme 2005; LAmbdon et al., 2008; Villa et al., 2011). Thus, apart from the general threat posed to native flora, in protected areas, in particular, biological invasions are disturbing drivers for ecosystem functioning, as well as for species, species communities or habitats (DE POORTER et al., 2007).

*Corresponding author:

e-mail: mondy_ghe@yahoo.com 
Studies on invasive plant species have often relied on regional or country-level studies which have generally focused on species biological characteristics, inventories or records. However, the literature also provides relevant research which considers the role of some large-scale geographical factors in explaining the occurrence and spread of Invasive Terrestrial Plant Species (ITPS). LAMBDON et al. (2008) consider climate, geographical and economic factors essential in determining the level of invasion. There are studies considering the importance of more specific habitat characteristics (e.g. geomorphology, water chemistry and vegetation) as important driving forces of invasive species, especially at regional scales (Loo et al., 2009).

The establishment and spread of invasive species can be influenced by a variety of factors (UNDERWOOD et al., 2004), which include the interaction of multiple environmental factors. Relief features (hypsometry, fragmentation, slope exposure and declivity) are either favourable or restrictive driving forces for species' development, ultimately leading to the differentiation of other natural factors (e.g. climate, soils, vegetation) (GRIGORESCU et al., 2016b). Climate conditions (e.g. temperature, precipitation) are considered major constraints to species' distribution at the global scale (HiJmans and GraHAm, 2006; MOKANY and FERrier, 2010; GALLARDO, 2014), although, at regional and local scales it has been proved species' high adaptation capabilities (PEARMAN et al., 2008). They often tolerate disturbed sites, establishing in areas affected by such as drought, fire or floods (MACK and D'ANTONIO, 1998; GRIGORESCU et al., 2016b). Rivers are considered natural vectors and dispersal factors enabling the spread of invasive species (FENESI et al., 2009), while wetlands are becoming niches that favour the penetration of invasive species driven by the regular hydrological imbalances (floods) that destroy the riparian vegetation (GRIGORESCU et al., 2016b,c).

Human activities can influence the penetration and establishment of invasive species through their introduction as ornamental trees in parks, gardens or forest plantations and anti-erosion protective belts, as well as the disturbances caused by the related impacts on various ecosystems: e.g. agriculture via land fragmentation, agricultural pollution, land abandonment; forest exploitation, habitat fragmentation and land degradation; overgrazing through land degradation and biodiversity loss etc. All of the above creating empty niches to be invaded by invasive species. Moreover, socio-economic activities, such as transport, trade and tourism, are directly connected to the introduction pathways and eventually the establishment and spread of invasive species. More exactly, sea ports and the related infrastructure are important gateways for invasive species; roads, railways and canals are also potential corridors along which invasive species spread (Hulme, 2009). These transport infrastructures are considered highly disturbed areas per se, thus providing favourable environments where invasive species can set and increase in abundance (BAx et al., 2003). Some authors associate socio-economic factors to a state of vulnerability of ecosystems enhanced by the high population densities, extended use of ecosystems and habitat degradation (GALLARDO, 2014). As a result, invasive species have proven their capacities to increase their rates of invasion in highly dense areas (PYšEK et al., 2010) and areas with an excess of nutrients derived from human activities (GALLARDO, 2014), thus successfully adapting to degraded and sensitive ecosystems.

Since the invasive species have become biological hazards with significant impacts on forest ecosystems and agricultural lands, the present paper is aiming to (1) highlight the role of some biophysical and anthropogenic factors in their distribution, (2) to assess some environmental implications and (3) to explore the modelling approaches of their potential distribution based on illustrative examples investigate by the authors and using the information provided by the scientific literature.

\section{ITPS in the Romanian protected areas}

In Romania, from the beginning of 18 th century when the first invasive species were signalled, the literature has been enlarged continuously by numerous works providing essential information on the systematic, taxonomic and floristic research synthesised by ANASTASIU and NEGREAN (2005); SĂVulescu (1952-1972), CiocÂrlan (19881990, 2000, 2009), Sîrbu et al. (2011, 2012), OpreA et al. (2011, 2012), Sîrbu and OpREA (2013). The latest records on the invasive flora of Romania referred to 671 species, of which 112 are considered genuine invasive owing to their high adaptive capacity, ability to spread in nature and the negative impacts on biodiversity and human health (Sîrbu and Oprea, 2011; Sîrbu et al., 2016a). Acknowledging the magnitude of the (potential) impacts ITPS have on protected areas, recent studies have turned their attention to the assessment of invasive species in Natura 2000 sites and large protected areas focusing on complex evaluations (e.g. origin and geographic distribution, biology, habitat description) (DuMITRAșcu et al., 2011, 2012, 2014; Dumitrașcu and Grigorescu, 2016; Grigorescu et al., 2016b; NiCULESCU et al., 2016; SĂMĂRGHIŢAN et al., 2018); chorology and ecology (DorofteI, 2009a, b); biological indicators (DOROFTEI et al., 2016); climate change-related impacts (DOROFTEI and ANASTASIU, 2014); modelling the potential distribution (KuCSICSA et al., 2013, 2016, 2018; Grigorescu et al., 2016a, c). Thus, among all analysed ITPS in the Romanian protected areas, ten have been identified as the most widespread, of which the most studied were Amorpha fruticosa, Ailanthus altissima, Acer negundo, Fallopia japonica and Impatiens glandulifera (Dumitrascu and Grigorescu, 2016).

In 2016, the results of the FP7 project enviroGRIDS (Building Capacity for a Black Sea Catchment Observation and Assessment System supporting Sustainable Development; www.envirogrids.net) were assembled in a synthesis book focused on the assessment of the main invasive plant species in Romanian protected areas. This book was a first geographical synthesis to connect species with the natural and human-induced conditions in various habitat types (Dumitrașcu and Grigorescu, 2016) which 
also opened up a new road for the development of a GISbased methodology aimed at modelling the areas with different potential distribution based on species frequency in relation to specific explanatory factors.

In the present study, three of the key invaders in protected areas are analysed: Amorpha fruticosa in Danube Delta Biosphere Reserve, Mureș Floodplain and Comana Natural Parks; Ailanthus altissima in Măcin Mountain National Park and Danube Delta Biosphere Reserve; Fallopia japonica in Maramureș Mountains Natural Park, Mureș Floodplain Natural Park and Rodna Mountains National Park (Fig. 1).

Amorpha fruticosa (the desert false indigo or the indigo bush) is a species that originates in the south-eastern part of North America. It was introduced in Romania in the first half of the 20th century for decorative purposes and the protection of degraded land (with Salix). Shortly, A. fruticosa breaks through the natural Populus and Salix forests along the Danube River. At the end of the 20th century, the species becomes invasive, increasing widening its habitat over extended areas (STǍNESCU et al., 1997).

Species main preference for wetland habitats (e.g. poplar or willow galleries, almond willow-osier scrubs, waterfringing reedbeds, riverine and lakeshore scrubs) has been systematically proven by the investigations carried out in Danube Floodplain and Danube Delta by ANASTASIU and Negrean (2005), Anastasiu et al. (2008), Dihoru (2004), Doroftei (2009a, b), Dumitraşcu et al. (2014), in Comana Natural Park by Dumitrașcu et al. (2011) or in Mureș Floodplain Natural Park by KucsicsA et al. (2018). Species preference for water proximity (Fig. 2a, b) and alluvial soils has been particularly demonstrated by the field surveys carried out by the authors. However, in other stands A. fruticosa was found to be highly adapted to the sylvosteppe soils characterised by reduced soil moisture, as shown by the studies carried out in Comana Natural Park where it largely spreads over reddish-brown soils with loam clay texture enriched in nitrogen, potassium and phosphorus. Overall, these findings prove species high adaptability to various environments. Due to the soil enrichment in organic matter, the specie was found in eutrophic ponds alongside reed species (Phragmites communis) slowly trying to substitute them, but also along main transport routes in relation to the spoiled soils (Dumitrașcu et al., 2011; Dumitraşcu et al., 2014). The species occurrence also suggest its invasive potential on meadows and bushes (SĂRăŢEANU, 2010), pastures (Fig. 2c) and along the edges of arable lands (mainly abandoned, non-used) (Kucsicsa et al., 2018). Large areas covered with $A$. fruticos $a$ were also identified in the proximity of transport routes, including railways (ANASTASIU et al., 2008; DumitraşCu et al., 2013; DumitraşCU et al., 2014;

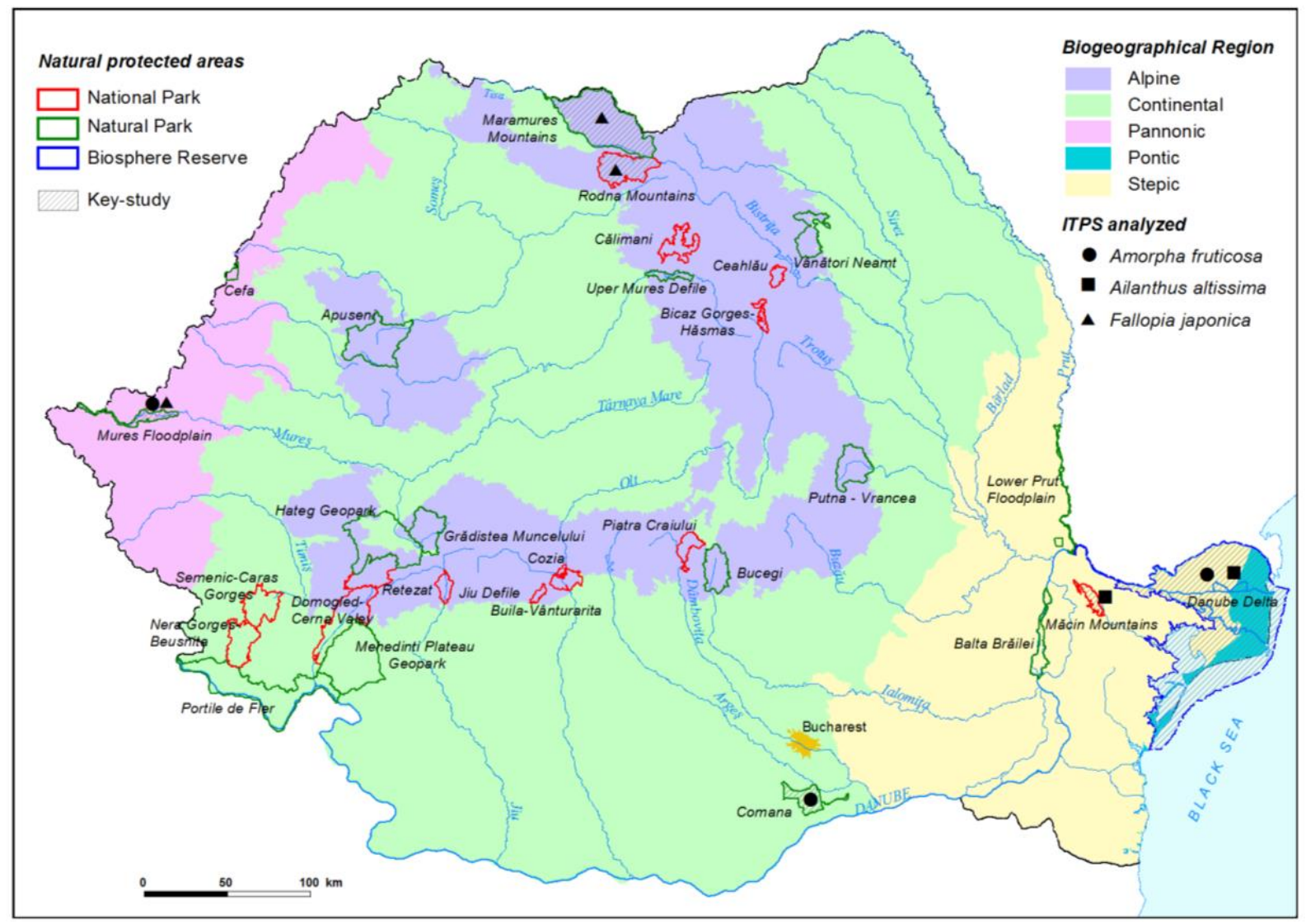

Fig. 1. Location of the analysed protected areas and the occurrence of ITPS. Authors' own elaboration using the GIS data provided by the Ministry of Environment, Water and Forests. 
(a)

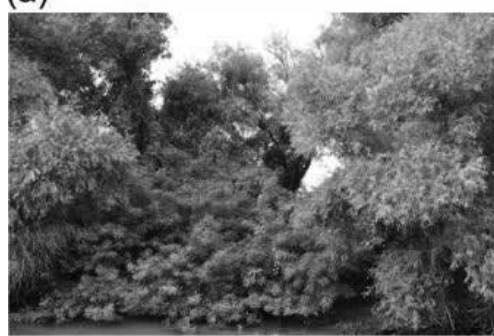

(d)

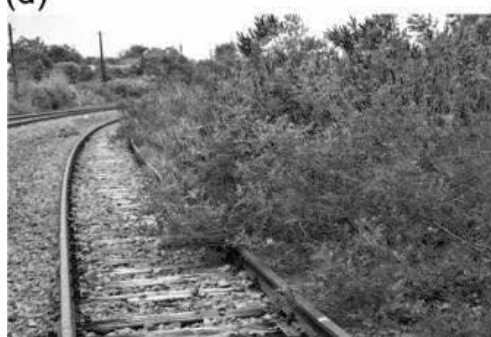

(b)

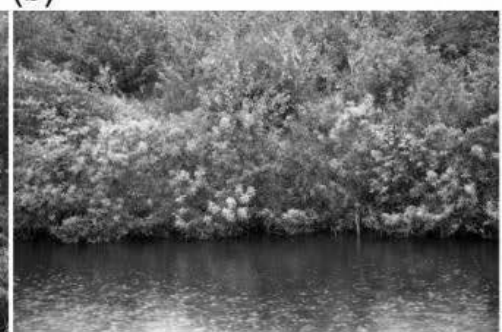

(e)

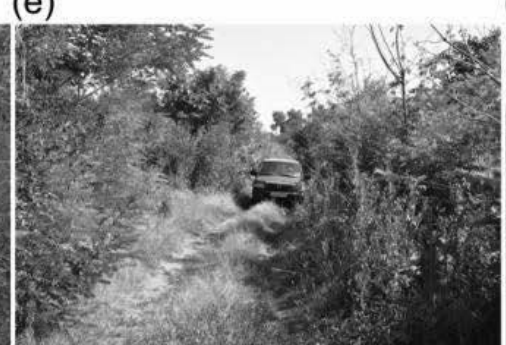

(c)

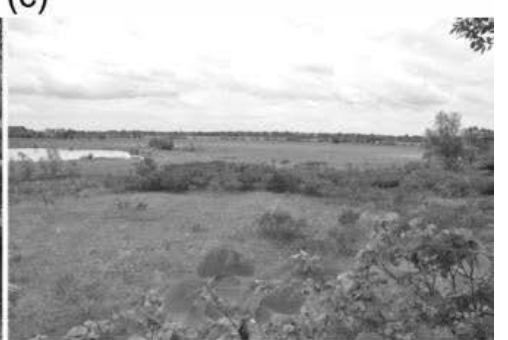

(f)

Fig. 2. A. fruticosa occurring along water bodies - (a) Danube Delta Biosphere Reserve, (b) Comana Natural Park; in pastures - (c) Comana Natural Park; along railway line - (d) Comana Natural Park; next to forest road - (e) Mureș Floodplain Natural Park; and at forests outskirts - (f) Comana Natural Park. Photo by authors.

KuCsicsa et al., 2018) (Fig. 2d), these constituting excellent ways of introduction/dissemination and sources of contamination providing a favourable environment for its persistence (MARIAN et al., 2010; DuMITRAşCU et al., 2011; KuCSICSA et al., 2018). In the Mureș Floodplain Natural Park, field investigations revealed that $68 \%$ of the mapped species are located in the first $0.1 \mathrm{~km}$ and $91 \%$ in the first $0.2 \mathrm{~km}$ to transport network (KuCSICSA et al., 2018).

A. fruticosa is a light-loving species, mainly developing on sunny slopes with southern, south-eastern and south-western orientation (Dumitrașcu et al., 2011). Therefore, compact forests represent a limiting factor, the species was mainly spotted in forest glades and also along the forest roads (Fig. 2e), or at the contact between forested areas and arable lands (KuCSICSA et al., 2018) and in shrubs areas developed at forests outskirts (DUMITRAşCU et al., 2011) (Fig. 2f).

Ailanthus altissima (tree of heaven) is a deciduous tree native to China, widely introduced into Europe in the second half of the 18th century as an ornamental plant (Sîrbu and Oprea, 2011), especially in the Mediterranean basin (TRAVESET et al., 2008). In Romania, the species was introduced as an ornamental tree, and for protection of de- graded and inclined terrains (Sîrbu and Oprea, 2011). At present, the species is found in all the regions of the country, generally thriving in disturbed habitats, along roads and railways, in fallow grounds, ruderal places and debris deposits, dry meadows in steppe and forest-steppe areas, in forest edges or on riverbanks. In the invaded habitats it tends to form mono-dominant dense clusters, difficult to remove due to its high capacity of vegetative reproduction by means of sprouts, thus displacing the native vegetation (Sîrbu et al., 2016a). The field surveys on A. altissima occurrence in Măcin Mountains National Park indicate that the species largely occurs in the grassland ecosystems and rocky areas (Fig. 3). The soil physicochemical properties have shown a particular influence on species development since it generally prefers some specific soil types (litosoils and kastanozeoms) and textures (loamy and clay loam) with high mineral content, thus proving species' adaptation to spoiled and degraded terrains soils (DUMITRAşCU et al., 2011; 2012; GRIGORESCU et al., 2016a). Local topography has a particular influence on $A$. altissima development, the analysed frequency in relation to the slopes' exposure in Măcin Mountains National Park indicating high preference $(94.4 \%)$ for the shinny and semi-shinny slopes
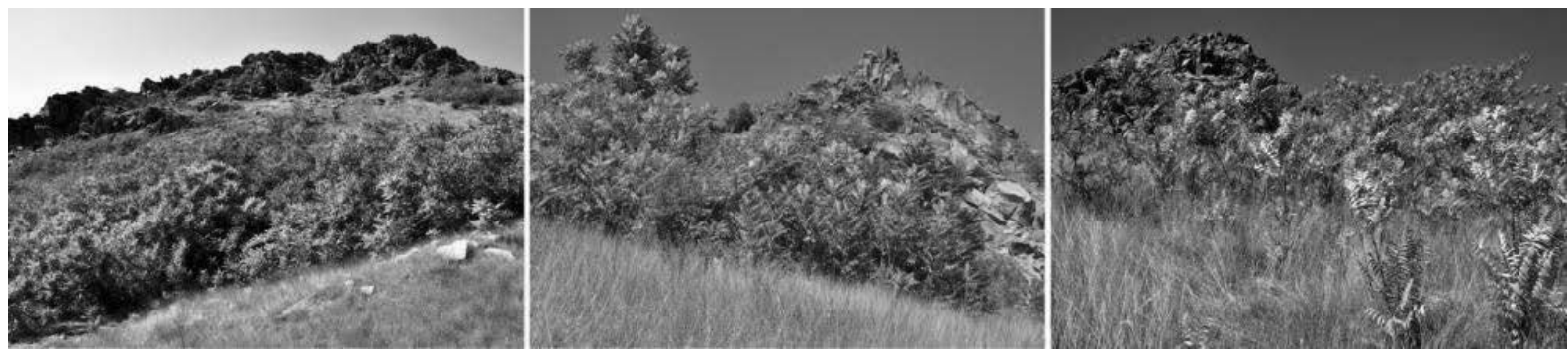

Fig. 3. A. altissima occurrence in Măcin Mountains National Park. Photo by authors. 
(GRIGORESCU et al., 2016a). Furthermore, the species also ranks among the most abundant invasive species in Danube Delta Biosphere Reserve where it is regularly found around lakes and river banks and in localities (DOROFTEI, 2009b; Doroftei and ANASTASIU, 2014).

Fallopia japonica (the Japanese knotweed), a.k.a. Polygonum cuspidatum or Reynoutria japonica is a herbaceous perennial plant native to eastern Asia. In the 19th century, the species was introduced into the United States of America and Europe (PYSEK, 2009; AguiLERA et al., 2010). As shown by the field surveys carried out in Mureş Floodplain Natural Park, Rodna Mountain National Park and Maramureş Mountains Natural Park (Dumitraşcu et al., 2012; KuCsiCSA et al., 2016), F. japonica has a preference for floodplains, riverbanks and open areas (free of coexisting species) (Fig. 4). The authors have noticed a higher dependency of the species to the fluvisols located in the floodplains of the main rivers rather than to the hypsometry or declivity. According to the relief characteristics, a high preference for shaded and semi-shaded habitats unfolded at lower altitudes of under $600 \mathrm{~m}$ (almost 100\%), and slope declivities of $<5^{\circ}$ (over $70 \%$ ) were found. Besides, the investigated plant communities of $F$. japonica in Mureş Floodplain Natural Park identified the species in riparian forests and shrubs developed close to the Mureș River. Among these, the main habitat type identified was Fraxino danubialis-Ulmetum, a rather dense association with $80 \%$ vegetation coverage, of which over $35 \%$ was represented by the Japanese knotweed (DOROFTEI et al., 2016).

\section{ITPS occurrence and environmental implications}

ITPS may have serious environmental implications affecting both biotic and abiotic components of ecosystems, disturbing its structure and function (CHARLES and DUKES, 2006), bringing in substantial costs to agriculture, forest and human health (Sîrbu et al., 2016a), and decreasing suitability of the soil for native species (CALLAWAY and RIDENOUR, 2004). These can become crucial, especially in protected areas, where risk on the native or endangered species can increase and therefore, biodiversity loss and soil degradation are expected.

A. fruticosa is considered a weak competitor in forests ecosystems because it is usually excluded by tree species
(Magyar, 1960). However, due to its fast growth, shading and probably its allelopathic effects (ELAKOwICH and Wooten, 1995) and nitrogen-fixing ability (WANG et al., 1999), it can significantly affect grasslands (SzIGETVÁRI, 2002). Our field-investigation demonstrate its invasive potential on pasturelands (Fig. 5a), but also on arable lands and especially forests outskirts (Fig. 5b, c), disturbing pastoral and agricultural activities and strongly limiting natural re-growth of native forest species. Furthermore, its high adaptability to a variety of environments is also demonstrated by its preference for metal-contaminated soils, especially on tailing ponds as pioneer species together with other fast-growing non-native and native species (MARIAN et al., 2010). Hence, the soil sampling carried in selected perimeters with $A$. fruticosa versus perimeters without $A$. fruticosa in different habitats included in protected areas revealed significant differences in heavy metals (DOROFTEI et al., 2016). For example, the investigations carried out in the Danube Delta Biosphere Reserve revealed that Ni exceeds with about $44 \mathrm{mg} \mathrm{kg}^{-1}$, Cr with $35 \mathrm{mg} \mathrm{kg}^{-1}$, Zn with $15 \mathrm{mg} \mathrm{kg}^{-1}$, Cu with $4 \mathrm{mg} \mathrm{kg}^{-1}$ and $\mathrm{Pb}$ with $3 \mathrm{mg} \mathrm{kg}^{-1}$ in samples collected from perimeters with $A$. fruticosa comparing to samples from the perimeters without $A$. fruticosa.

$A$. altissima has high invasive potential to establish into degraded sites disturbed by natural events, i.e. drought, storms, insects infestations, forest fires (TRIFILO et al., 2004; Ditomaso et al., 2006) or man-made activities, i.e. railroad embankments, waste grounds (FERET, 1985) where can threaten biodiversity and alter the invaded ecosystems (ViLA et al., 2006; BaDalamenti and LA Mantia, 2013). Our research in Măcin Mountains National Park revealed the excellent ability of the A. altissima to establish in different environmental conditions, its spreading and growth capacity increasing even on rocky areas (Fig. 5d) and abandoned agricultural lands (Fig. 5e). Besides, continuous transformation of natural ecosystems by human activity that determined replacement of primeval forest and sylvo-steppe vegetation with secondary meadows and scrub associations had led to species invasions in many areas in the southern and south-eastern Romania. In such modified habitats, A. altissima associations have also been identified in Comana Natural Park (Grigorescu et al., 2016c).

$F$. japonica is also known for its capacity to tolerate a variety of natural and disturbed environments (e.g. railroad tracks, roadsides). The species is broadly regarded as (a)

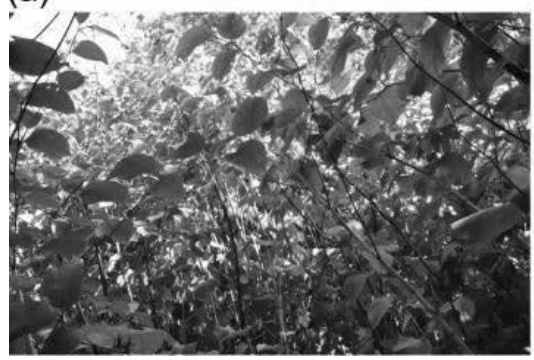

(b)

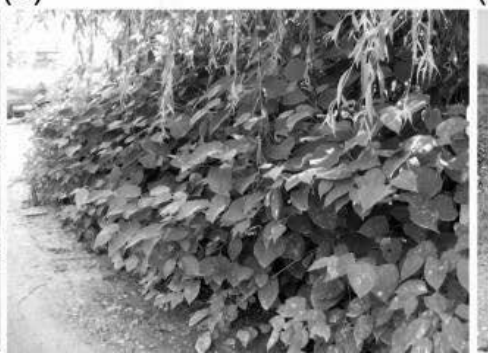

(c)

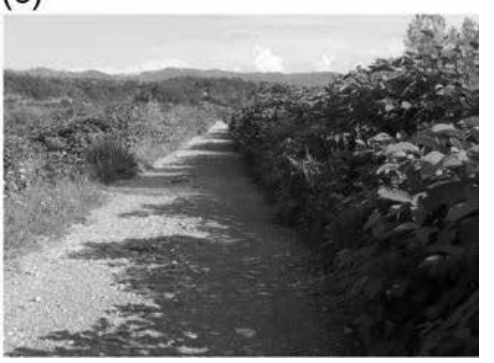

Fig. 4. Fallopia japonica occurring in Mureş Floodplain Natural Park (a), Rodna Mountain National Park (b) and Maramureş Mountains Natural Park (c). Photo by authors. 
(a)

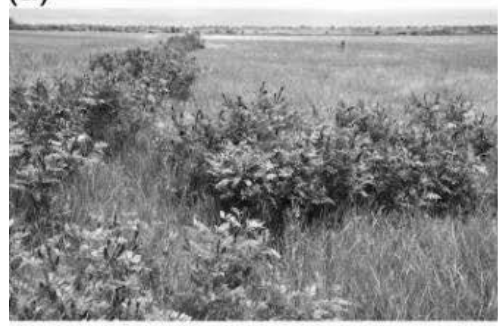

(d)

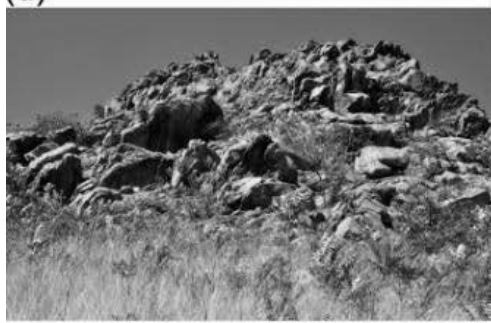

(g)

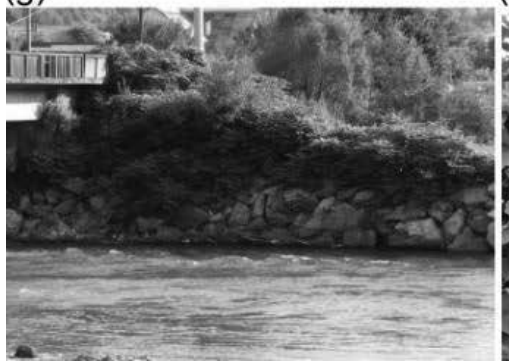

(b)

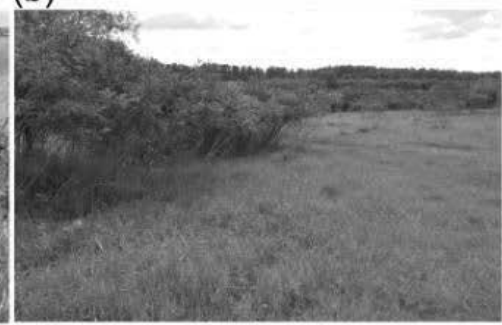

(e)

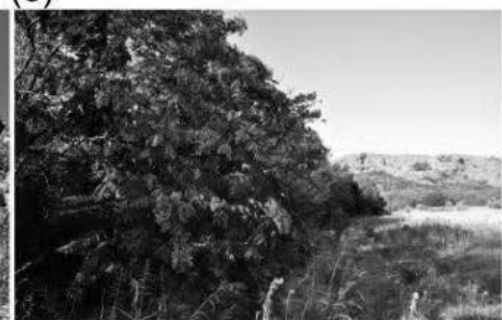

(h)

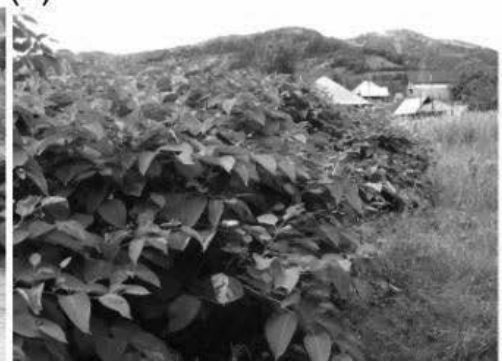

(c)

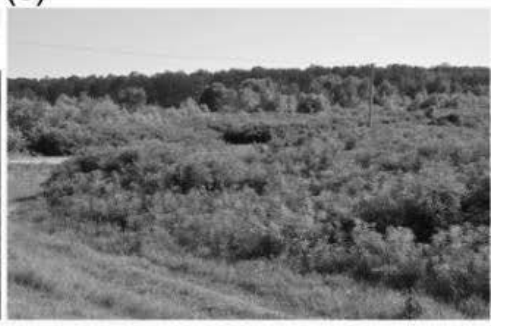

(f)

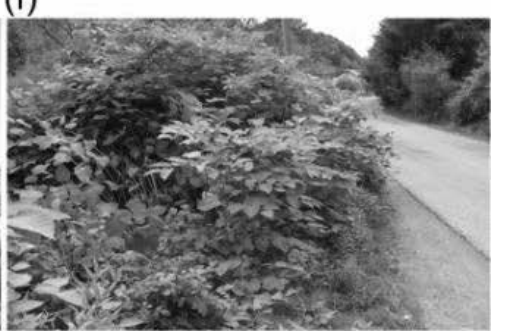

(i)

Fig. 5. A. fruticosa occurring on pastures - (a) Comana Natural Park and forests outskirts - (b) Comana Natural Park, (c) Mureş Floodplain Natural Parks. A. altissima tendency to spread on rocky areas - (d) Măcin Mountains National Pak and abandoned arable lands - (e) Măcin Mountains National Pak. F. japonica occurring along the asphalted road - (i) Maramureş

Mountains Natural Park, riverbanks - (g) Maramureş Mountains Natural Park and inside the settlements - (h) Maramureş Mountains Natural Park. The stems density - (i) Maramureş Mountains Natural Park. Photo by authors.

one of the most invasive plant species in Europe (LAMBDON et al., 2008) especially due to its high capacity of generating huge amounts of rhizomes that often cause damage to riverbanks, penetrating and displacing foundations and drainage works (BEERLING, 1991). Its strong root with a high penetrating capacity even on long lengths can become a real problem not only in the Maramureș Mountain Natural Park, but also in many other areas from the Carpathian Mountains and hilly regions, where the high occurrence along with the transport infrastructure (Fig. 5f), riverbanks (Fig. 5g) or inside the settlements (Fig. 5h) can affect the asphalted roads, buildings and agricultural lands. At the same time, it is widely recognized that this species forms dense patches, significantly reducing the diversity of native species, shading up other plants and slowing nutrient cycling (AguiLERA et al., 2010). Our assessment in Maramureș Mountain Natural Park (along the Ruscova and Vișeu floodplains) confirmed high extension capacity by developing density of individual stems (Fig. 5i) up to 50/sq.m. (Dumitraşcu et al., 2012), thus causing significant limitation in native species development in the area.

In protected areas, in particular, species' location in relation to management areas (zoning) is important, especially when analysing the impact on native or endangered species and developing eradication measures. Thus, in the mapped areas, the high shares of $A$. altissima in Măcin Mountains National Park (Grigorescu et al., 2016a) and A. fruticosa in Comana Natural Park (Grigorescu et al., 2016c) found in the totally protected area suggest significant susceptibility to invasion in the important habitats and critical ecosystems. Under these circumstances, continued monitoring and comprehensive studies on the species characteristics and occurrence, on the one hand, and developing appropriate eradication and control methods, on the other, are highly recommended in order to preserve essential ecosystems and specific habitats for the native species.

\section{Modelling ITPS occurrence in relation to their driving factors}

Given that limited resources are available for the control of invasive plant species (GoSLEE et al. 2006), the modelling of ITPS potential distribution based on the mapped occurrence and key driving factors can provide a useful tool for investigating its potential occurrence at different spatial scales. Hence, species distribution models attempt to provide detailed spatial data in order to increase the capacity 
(a)

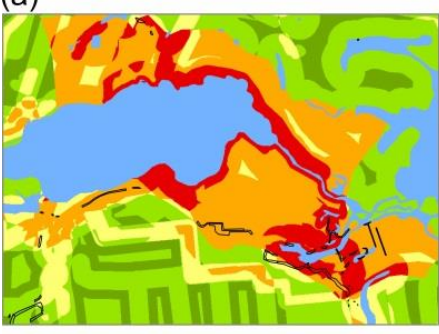

(b)

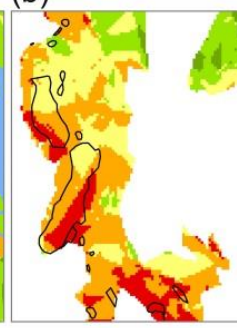

(c)
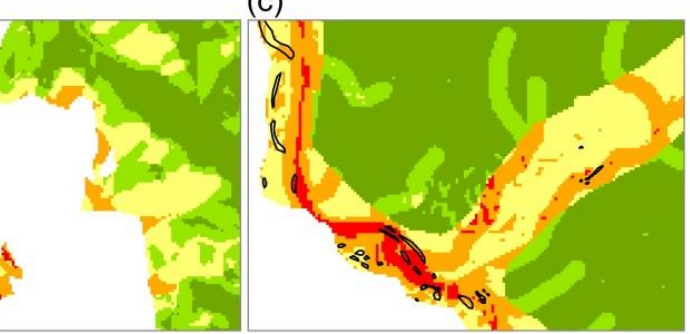

(d)

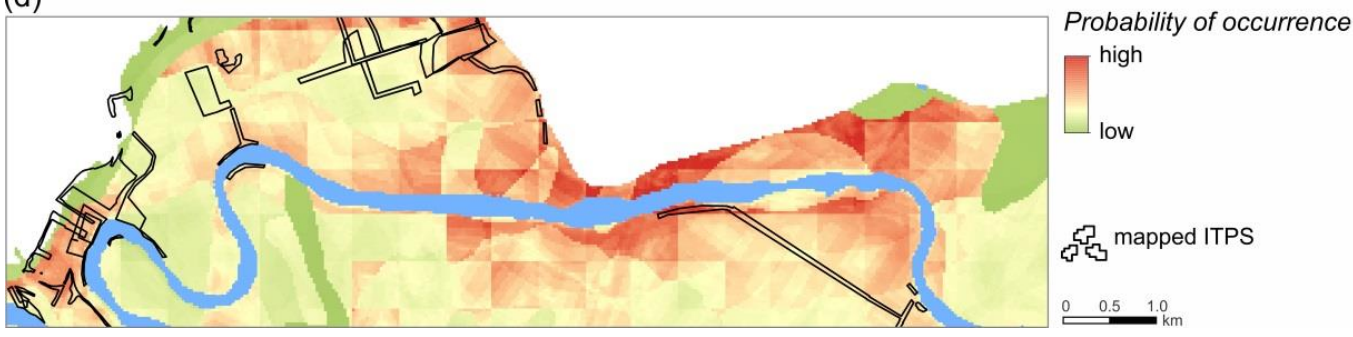

Fig. 6. Samples maps illustrating the potential distribution of A. fruticosa in Comana Natural Park (a), A. altissima in Măcin Mountains National Park (b) and F. japonica in Maramureș Mountains Natural Park (c), based on its frequency in the analysed driving factors, and the calculated probability of A. fruticosa occurrence in Mureş Floodplain Natural Park (d), based on the relationship between the species and its driving factors, estimated empirically by using binary logistic regression. Authors' own elaboration.

control and monitoring in sensitive areas and to implement appropriate planning strategies for the limitation and eradication. The integrated interdisciplinary studies carried out within FP7 enviroGRIDS project opened up a new road for the development of a GIS-based methodology aimed to analyse and model the suitability areas at different scale for the terrestrial invasive species in Romania. Thus, based on the ITPS frequency in relation to different natural and human-induced conditions (e.g. relief-related local topography, soil characteristics, land-use/cover pattern or proximity to water bodies and transport infrastructure) simple spatial models were developed and applied in order to estimate potential distribution of $A$. fruticosa (DUMITRAşCU et al., 2011; KuCsicsa et la. 2013; GrigoresCU et al., 2016c), A. altissima (Grigorescu et al., 2016a) and $F$. japonica (KuCsicsA et al., 2016). According to these, five classes have been resulted, indicating the estimated potential distribution (very low, low, medium, high and very high) across the areas (Fig. 6a-c). Furthermore, by integrating statistical analysis, a complex method was developed and applied to estimate $A$. fruticosa occurrence in the Mureş Floodplain Natural Park (KuCsicsA et al., 2018). Specifically, a relationship between the ITPS and more selected driving factors (including forest fragmentation, NDV distribution values and depth to water) was empirically estimated using binary logistic regression. Hence, obtained regression coefficients were integrated into GIS spatial analysis in order to estimate the "preference" of ITP for the location characteristics, expressed in probability values from 0 (low) to 1 (high). In addition, the model also assessed the relative contribution of the included explanatory factors for ITPS, their hierarchy and statistical significance. Besides, the statistical ROC-AUC (Receiver Operating Characteristic-Area Under the Curve) and spatial cross-classification analysis, by overlaying the predicted results and the real occurrence of ITPS, were also used to evaluate the performance of the predicted map.

\section{Conclusions}

In the last decades, the landscapes of protected areas have become subject to various transformations due to natural stressors (e.g. extreme weather events, extended droughts, wind-throw, avalanches) and human activities such as tourism (Comana Natural Park), forest exploitation and overgrazing (Rodna Mountains National Park, Maramureș Natural Park), overexploitation of natural resources (Maramureș Mountains Natural Park). As a result, the floristic structure and composition of natural ecosystems have been significantly changed, and the primeval vegetation has been often altered, thus favouring the penetration of different invasive plant species into native habitats. In this respect, it is easy to understand that the more ecosystems and habitats are affected by disturbance, the more likely they become invaded by ITPS. Thus, although restricted due to protected areas status, most of the environmental changes (e.g. future forest fragmentation and clearing, extension of the transportation network and the abandonment of the agricultural lands) will lead, in time, to the increase in their occurrence. Moreover, planting for different purposes (reclamation of degraded lands, protection of dams or roads, greening of mining areas) create a direct way to disturb the life of indigenous herbaceous and forest species. Besides, since the river system is considered as main transport corridors for the invasive plants, characterised by natural disturbances that create suitable sites, it can be appreciated that the ITPS occurrence in the analysed protect- 
ed areas could represent an important ecological issue for even more large regions. This can become critical given that the Mureş Floodplain and Comana Natural Parks, and especially Danube Delta Biosphere Reserve which overlap large wetland areas where fluctuating water level and longtime anthropogenic disturbance, facilitate these invasions.

Given that these invasive plants are strongly associated with some biophysical and anthropogenic factors, the present-study proposed to increase the knowledge of the ITPS and to provide an important starting point for further analysis of spreading and threat for the native plant species. Furthermore, understanding how ITPS evolve and varies across geographic space is important in the way we should address the conservation of native ecosystems and to identify and implement necessary management strategies for the control of non-native species. So far, the control and/or eradication of invasive species in Romania have not been of particular concern. However, without a national strategy in this respect, only local eradications actions were noticed in protected areas, as well as in agriculture and forestry (SîRBu et al., 2016b). Only recently, the updating of the National Strategy for Biodiversity Conservation was enriched with new information and recommendations on reducing the negative impacts of invasive on native species and habitats, which would significantly contribute in the future to adopting and implementing control measures in protected areas.

\section{Acknowledgement}

The study has been developed in the framework of the FP7 - Building Capacity for Black Sea Catchments Observation and Assessment System supporting Sustainable Development (EnviroGRIDS); http://www.envirogrids.net/.

\section{References}

Aguilera, A., Alpert, P., Dukes, J.S., Harrington, R., 2010. Impacts of the invasive plant Fallopia japonica (Houtt.) on plant communities and ecosystem processes. Biological Invasions, 12: 1243-1252. doi: 10.1007/ s10530-009-9543-z.

Anastasiu, P., Negrean, G., 2005. Alien plants in Romania. Analele Ştiinţifice ale Universităţii "Alexandru Ioan Cuza” din Iaşi (Serie nouă). Secțiunea 2a. Biologie Vegetală, 51: 87-96.

Anastasiu, P., Negrean, G., 2008. New alien plants to Romania. Analele Universităţii din Craiova. Seria Agricultură, Montanologie, Cadastru, 38: 1-10.

Anastasiu, P., Negrean, G., Başnou, C., Sîrbu, C., Oprea, A., 2008. A preliminary study on the neophytes of wetlands in Romania. In RABITSCH, W. Biological invasions - from ecology to conservation. Neobiota, 7. Berlin: Institute of Ecology of the TU Berlin, p. 181-191.

Badalamenti, E., La Mantia, T., 2013. Stem-injection of herbicide for control of Ailanthus altissima (Mill.) Swingle: a practical source of power for drilling holes in stems. iForest: Biogeosciences and Forestry, 6 (3): $123-126$.
Bax, N., Williamson, A., Aguero, M., Gonzalez, E., GeEves, W., 2003. Marine invasive alien species: a threat to global biodiversity. Marine Policy, 27: 313-323.

BeERLING, D.J., 1991. The testing of cellular concrete revetment blocks resistant to growths of Reynoutria japonica Houtt. (Japanese knotweed). Water Reserach, 25: 495498.

Callaway, R.M., Ridenour, W.M., 2004. Novel weapons: invasive success and the evolution of increased competitive ability. Frontiers in Ecology and the Environment, 2 (8): 436-443. https://doi.org/10.1890/15409295(2004)002[0436:NWISAT]2.0.CO;2

Charles, H., Dukes, J.S., 2006. Impacts of invasive species on ecosystem services in ecological studies. Biological Invasions, 193: 9-15.

CiocÂrlan, V. (coord.), 1988-1990. Flora ilustrată a României. Vol. 1, Vol. 2 [Illustrated flora of Romania]. Bucureşti: Editura Ceres. 897 p.

Ciocârlan, V., 2000. Flora ilustrată a României: Pteridophyta et Spermatophyta [Illustrated flora of Romania]. 2. ed. Bucureşti: Editura Ceres. 1138 p.

CiocÂrlan, V., 2009. Flora ilustrată a Romaniei: Pteridophyta et Spermatophyta [Illustrated flora of Romania]. 3. ed. Bucureşti: Editura Ceres. 1141 p.

De Poorter, M., Pagad, S., Ullah, M.I., 2007. Invasive alien species and protected areas: a scoping report. Part I. Scoping the scale and nature of invasive alien species threats to protected areas, impediments to IAS management and mean to address those impediments. [online]. Produced for the World Bank as a contribution to the Global Invasive Species Programme (GISP). [cit. 202003-30]. http://www.issg.org/pdf/publications/gisp/resources/ias_protectedareas_scoping_i.pdf.

Dihoru, G., 2004. Invasive plants in Romania's flora. Analele Universităţii din Craiova, 9 (45): 73-82.

Ditomaso, J.M, Brooks, M.L, Allen, E.B, Minnich, R., Rice, P.M, Kyser, G.B., 2006. Control of invasive weeds with prescribed burning. Weed Technology, 20: 535-548. https://doi.org/10.1614/WT-05-086R1.1

Doroftei, M., 2009a. Chorology of Amorpha fruticosa in Danube Delta. Romanian Journal of Plant Biology, 54 (1): 61-67.

DorofteI, M., 2009b. Ecology of some alien plant species in Danube Delta. Ovidius University Annals of Natural Sciences, Biology - Ecology Series, 9 (1): 33-40.

Doroftei, M., Anastasiu, P., 2014. Potential impacts of climate change on habitats and their effects on invasive plant species in Danube Delta Biosphere Reserve, Romania. In Rannow, S., Neubert, M. (eds). Managing protected areas in Central and Eastern Europe under climate change. Dordrecht: Springer, p. 267-278.

Doroftei, M., Grigorescu, I., Dumitraşcu, M., KucSICSA, G., 2016. Key indicators in assessing of invasive terrestrial plant species in Romanian protected areas. In Dumitraşcu, M., Grigorescu, I. (eds). Invasive terrestrial plant species in the Romanian protected areas. A geographical approach. Bucureşti: Editura Academiei Român, p. 64-74.

Doroftei, M., Kucsicsa, G., Grigorescu, I., Dumitraşcu, M., Ferus, P., Herlo, G., NĂstase, M., 2016. Linkages between ecological features and Amorpha fruticosa 
(mill.) occurrence in selected protected areas from Romania and Slovakia. Preliminary results. In RIES C., KRIPPEL, Y. (eds), 2016. Biological invasions: interactions with environmental change. Book of abstracts. NEOBIOTA 2016 - 9th international conference on biological invasions. Vianden, Luxembourg, 14-16 September 2016. Luxembourg: Fondation faune-flore, p. 142.

DumitraşCu, M., Grigorescu, I. (eds), 2016. Invasive terrestrial plant species in the Romanian protected areas. A geographical approach. Bucureşti: Editura Academiei Române. 155 p.

Dumitraşcu, M., Grigorescu, I., Doroftei, M., KuCsicsa, G., Mierlă, M., Dragotă, C., Năstase, M., 2013. Amorpha fruticosa in three wetland areas: Danube Delta Biosphere Reserve, Comana and Mureş Floodplain Natural Parks. International Multidisciplinary Scientific GeoConference: SGEM: Surveying Geology \& Mining Ecology Management, 1: 113-124.

Dumitraşcu, M., Grigorescu, I., Kuscicsa, G., Doroftei, M., NĂSTASE, M., DraGotĂ, C.S., 2014. Invasive terrestrial plant species in the Romanian protected areas. A geographical approach. Romanian Journal of Geography, 58 (2): $145-160$

Dumitraşcu, M., Grigorescu, I., Kucsicsa, G., Dragotă, C.S., NĂSTASE, M., 2011. Non-native and native invasive terrestrial plant species in Comana Natural Park. Casestudies: Amorpha fruticosa and Crategus monogyna. Romanian Journal of Geography, 55 (2): 81-89.

Dumitraşcu, M., Kucsicsa, G., Grigorescu, I., Dragotă, C.S., NĂSTASE, M., 2012. Invasive terrestrial plant species in the Romanian protected areas. Case study: Fallopia japonica in Maramureş Mountains Natural Park. Geographical Phorum, 11 (1): 45-53.

ElaKowich, S.D., Wooten, J.W., 1995. Allelopathyc woody plants I. Abies alba through Lyonia lucida. Allelopathy Journal, 2: 117-146.

Fenesi, A., RuPrecht, E.K., Vincze, E., 2009. Aggressively spreading exotic plant species in Romania. In Rakosy, L., Momeu, L. (eds). Neobiota din Romania. Cluj-Napoca: Presa Universitară Clujeană, p. 55-65.

FERET, P.P., 1985. Ailanthus: variation, cultivation, and frustration. Journal of Arboriculture, 11 (12): 361-368.

Gallardo, B., 2014. Europe's top 10 invasive species: relative importance of climatic, habitat and socio-economic factors. Ethology, Ecology \& Evolution, 26 (2-3): 130 151.

Goslee, S.C, Debra, P.C, Peters, D.P.C, Beck, G.K., 2006. Spatial prediction of invasion success across heterogeneous landscapes using an individual-based model. Biological Invasions, 8 (2): 193-200.

Grigorescu, I., Dumitraşcu, M., Kucsicsa, G., Doroftei, M., NĂStase, M., Dragotă, C.S., 2016a. Predicting the potential distribution of Ailanthus altissima invasive terrestrial plant species in Măcin Mountains National Park (Romania). In Koulov, B., Zhelezov, G. (eds). Sustainable development in mountain regions. Cham: Springer International Publishing, p. 159-172.

Grigorescu, I., Kucsicsa, G., Dumitraşcu, M., Doroftei, M., 2016b. Assessing invasive terrestrial plant species in selected protected areas in Romania. A geographical approach. In Dendrologické dni v Arboréte Mlyñany SAV 2016: dreviny v meniacom sa prostredí. Vieska nad
Žitavou: Arborétum Mlyňany SAV, detašované pracovisko Ústavu ekológie lesa SAV Zvolen, 2016, p. 113-120.

Grigorescu, I., Kucsicsa, G., Dumitraşcu, M., Năstase, M., Dragotă, C.S., 2016c. Potential distribution of Invasive Terrestrial Plant Species (ITPS) in the Romanian protected areas. ITPS in Comana Natural Park. In Dumitraşcu, M., GRIGORESCU, I. (eds). Invasive terrestrial plant species in the Romanian protected areas. A geographical approach. Bucureşti: Editura Academiei Român, p. 81-86.

Hijmans, R.J., Graham, C.H., 2006. The ability of climate envelope models to predict the effect of climate change on species distributions. Global Change Biology, 12: $2272-2281$.

Hulme, P.E., 2009. Trade, transport and trouble: managing invasive species pathways in an era of globalization. Journal of Applied Ecology, 46: 10-18.

Hulme, P.E., Nentwig, W., PyšEK, P., Vilì, M., 2009. Biological invasions: benefits versus risks response. Science, 324: 1015-1016.

Kucsicsa, G., Grigorescu, I., Dumitraşcu, M., 2013. Integrated methodology for the assessment of invasive terrestrial plant species potential distribution in the Romanian protected areas. A GIS-based approach. In Recent advances in environmental science. Proceedings of 9th international conference on energy, environment, ecosystems and sustainable development (EEESD'13). Energy, environmental and structural engineering series, 7. WSEAS Press, p. 150-155.

Kucsicsa, G., Grigorescu, I., Dumitraşcu, M., Năstase, M., 2016. Potential distribution of Invasive Terrestrial Plant Species (ITPS) in the Romanian protected areas. ITPS in Maramureș Mountains Natural Park. In Dumitrașcu, M., GRIGORESCU, I. (eds). Invasive terrestrial plant species in the Romanian protected areas. A geographical approach. Bucureşti: Editura Academiei Române, p. 87-92.

Kucsicsa, G., Grigorescu, I., Dumitraşcu, M., Doroftei, M., Năstase, M., Gabriel, H., 2018. Assessing the potential distribution of invasive alien species Amorpha Fruticosa (mill.) in the Mureş Floodplain Natural Park (Romania) using GIS and logistic regression. Nature Conservation, 30: 41-67.

Lambdon, P., Pyšek, P., Basnou, C., Hejda, M., ArianoutSOU, M., Essl, F. ANDriopoulos, P., 2008. Alien flora of Europe: species diversity, temporal trends, geographical patterns and research needs. Preslia, 80: 101-149.

Loo, S.E., Mac Nally, R., O’Dowd, D.J., Thomson, J.R., LAKE, P.S., 2009. Multiple scale analysis of factors influencing the distribution of an invasive aquatic grass. Biological Invasions, 11: 1903-1912.

MagYar, P., 1960. Alföldfásitás [Afforestation in Great Hungarian Plain]. Budapest: Akadémiai Kiadó, p. 86-104.

MACK, M.C., D’Antonio, C.M., 1998. Impacts of biological invasions on disturbance regimes. Trends in Ecology \& Evolution, 13 (5): 195-198.

Marian, M., Nicula, C., Mihaly-Cozmuta, L., Peter, A. Minaly-Cozmuta, A., 2010. Participation of the indigenous vs. alien herbaceous species to the constitution of vegetal layer on the Bozânta Mare tailing ponds. Analele Universitătii din Oradea, Fascicula Biologie, 17 (1): 134-141.

Mokany, K., Ferrier, S., 2010. Predicting impacts of climate change on biodiversity: a role for semi-mechanistic 
community-level modelling. Diversity and Distributions, 17: 374-380.

Niculescu, M., Făgăraş, M., Popescu, C., 2016. Diversity, distribution and ecology of the invasive alien plants in the Cotmeana Platform Protected Area, Romania. International multidisciplinary scientific geoconference: SGEM: Surveying Geology \& Mining Ecology Management, 1: 247-253.

Oprea, A., Sîrbu, C., Doroftei, M., 2011. New contributions to the flora of Romania. Analele Ştiinţifice ale Universităţii "Alexandru Ioan Cuza" din Iași (Serie nouă). Secţiunea 2a. Biologie Vegetală, 57: 79-90.

Oprea, A., Sîrbu, C., Eliáš, P. Jun., Ferus, P., 2012. New data addition to the Romanian alien flora. Journal of Plant Development, 19: 141-156.

Pearman, P.B., Guisan, A., Broennimann, O., Randin, C.F., 2008. Niche dynamics in space and time. Trends in Ecology \& Evolution, 23: 149-158.

PYŠEK, P., 2009. Fallopia japonica (Houtt.) Ronse Decr., Japanese knotweed (Polygonaceae, Magnoliophyta). In DAISIE. Handbook of alien species in Europe. Invading Nature, 3. Berlin: Springer. 348 p.

PYšEK, P., Hulme, P.E., 2005. Spatio-temporal dynamics of plant invasions: Linking pattern to process. Ecoscience, $12: 302-315$.

Pyšek, P., Jarošík, V., Hulme, P.E., KüHN, I., WiLd, J., ARIanoutsou, M., Bacher, S., Chiron, F., Didžiulis, V., Essl, F., Genovesi, P., Gherardi, F., Hejda, M., Kark, S., Lambdon, P.W., Desprez-Loustau, M.L., Nentwig, W., Pergl, J., Poboljšaj, K., Rabitsch, W., Roques, A., Roy, D.B., Shirley, S., Solarz, W., Vilà, M., Winter, M. 2010. Disentangling the role of environmental and human pressures on biological invasions across Europe. Proceedings of the National Academy of Sciences, 107 (27) 12157-12162. https://doi.org/10.1073/pnas.1002314107

RichARDSON, D.M., PYŠEK, P., 2012. Naturalization of introduced plants: ecological drivers of biogeographical patterns. New Phytologist, 196: 383-396.

Rojas-Sandoval, J., Tremblay, R.L., Acevedo-Rodríguez, P., DíAZ-Soltero, H., 2017. Invasive plant species in the West Indies: geographical, ecological, and floristic insights. Ecology and Evolution, 7 (13): 4522-4533.

SămĂrghițan, M., Oroian, S., TĂnase, C., 2018. Contributions to the study of the alien and invasive species in some protected areas in Mureș County, Romania. Acta Horti Botanici Bucurestiensis, 45: 33-46.

SĂRĂȚEANU, V., 2010. Assessing the influence of Amorpha fruticosa $\mathrm{L}$. invasive shrub on some grassland vegetation types from western Romania. Research Journal of Agricultural Science, 42 (1): 536-540.

Săvulescu, T. (ed.), 1952-1976. Flora Republicii Populare Române - Flora Republicii Socialiste România. Vols 1-13. București: Editura Academiei Republicii Populare Române, Academia Republicii Socialiste România.

Sîrbu, C. (ed.), Oprea, A., 2011. Plante adventive în flora Românei [Adventitious plants in the Romanian flora]. Iaşi: Editura "Ion Ionescu de la Brad". 733 p.

SîRBU, C., OpreA, A., 2013. A new contribution on the vascular flora of Romania. Acta Horti Botanici Bucurestiensis, 40: 19-26.
Sîrbu, C., Oprea, A., Doroftei, M., 2016a. Management and control of invasive terrestrial plant species in Romania. In Dumitraşcu M., Grigorescu, I. (eds). Invasive terrestrial plant species in the Romanian protected areas. A geographical approach. Bucureşti: Editura Academiei Române, p. 103-112.

Sîrbu, C., Oprea, A., Doroftei, M., 2016b. Invasive terrestrial plant species in Romania. In Dumitraşcu M., GRIGORESCU, I. (eds). Invasive terrestrial plant species in the Romanian protected areas. A geographical approach. Bucureşti: Editura Academiei Române, p. 17-29.

Sîrbu, C., Oprea, A., Eliáš, P. Jun., Ferus, P., 2011. New contribution to the study of alien flora in Romania. Journal of Plant Development, 18: 121-134.

Sîrbu, C., Oprea, A., Eliášs, P. Jun., Ferus, P., 2012. New data addition to the Romanian alien flora. Journal of Plant Development, 19: 141-156.

StĂnescu, V., ŞofleteA, N., Popescu O., 1997. Flora forestieră lemnoasă a României [Romania's ligneous forest flora]. Bucureşti: Ceres. $452 \mathrm{p}$.

SzigetváRI, C., 2002. Initial steps in the regeneration of a floodplain meadow after a decade of dominance of an invasive transformer shrub, Amorpha fruticosa L. Tiscia, 33: 67-77.

Traveset, A., Brundu, G., Carta, L., Mprezetou, I., LambDon, P., Manca, M., Suehs, C.M., 2008. Consistent performance of invasive plant species within and among islands of the Mediterranean basin. Biological Invasions, 10 (6): 847-858.

Trifilo, P., Raimondo, F., NARdini, A., Lo Gullo, M.A., SAlLeo, S., 2004. Drought resistance of Ailanthus altissima: root hydraulics and water relations. Tree Physiology, 24 (1): 107-114.

Underwood, E.C., Klinger, R., Moore, P.E., 2004. Predicting patterns of non-native plant invasions in Yosemite National Park, California, USA. Diversity and Distributions, 10 (5-6): 447-459.

Vilà, M., Tessier, M., Suehs, C.M., Brundu, G., Carta, L., Galanidis, A., Lambdon, P., Manca, M., Médail, F., Moragues, E., Traveset, A., Troumbis, A.Y., Hulme, P.E., 2006. Local and regional assessments of the impacts of plant invaders on vegetation structure and soil properties of Mediterranean islands. Journal of Biogeography, 33 (5): 853-861.

Vilà, M., Espinar, J.L., Hejda, M., Hulme, P.E., Jarošík, V., Maron, J.L, Pergl, J., Schaffner, U., Sun, Y., Pyšek, P., 2011. Ecological impacts of invasive alien plants: a meta-analysis of their effects on species, communities and ecosystems. Ecology Letters, 14: 702-708.

Wang, E.T., Van Berkum, P., Sui, X.H., Beyene, D., Chen, W.X., MartíneZ-Romero, E., 1999. Diversity of microbial associated with Amorpha fruticosa isolated from Chinese soils and description of Mesorhizobium amorphae sp. nov. International Journal of Systematic Bacteriology, 49 (1): 51-65. https://doi.org/10.1099/00207713-49-1-51

Received May 7, 2020 Accepted July 8, 2020 